\title{
ET MENNESKE I OLDTIDEN
}

\section{Bruno Ingemann}

Kan man finde mennesker pa Nationalmuseets udstilling om Oldtiden? Der er selvfolgelig de besugende. Men hvad med sporene af oldtidens mennesker og de relationer de kan have haft til hinanden?

Her er der to rode figurer pà en hvid bund. De er placeret $i$ en montre hvor der svaver

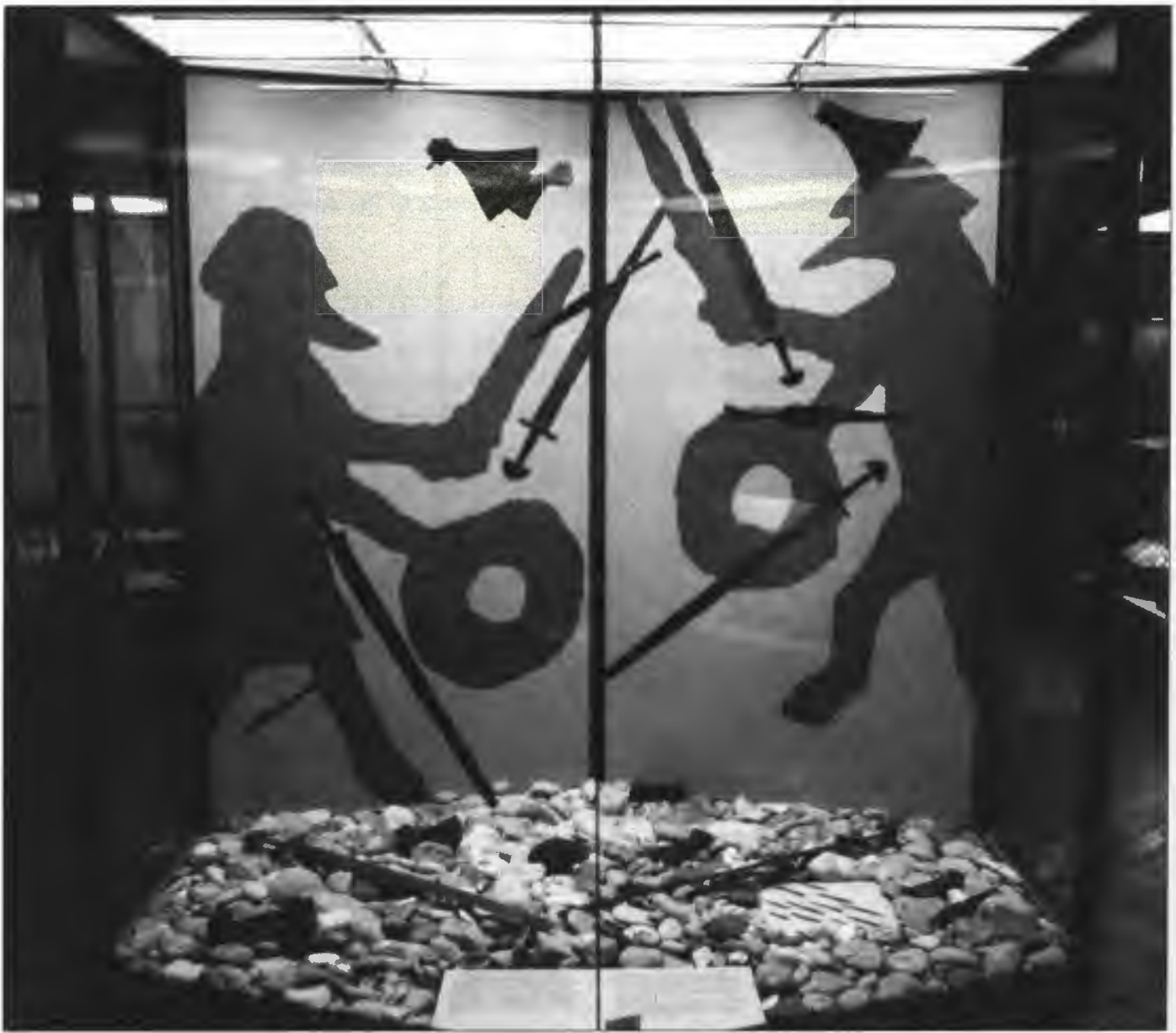


fire svard og to øksehoveder. Og $i$ bunden af montren er der en masse sten og ovenpa dem ligger der yderligere to svard og fire øksehoveder. Vi er i vikingetiden. Her er det meget tydeligt at der gennem den grove visuelle reprasentation af to mennesker skabes en relation mellem dem gennem en handling. Jeg kan opleve dem som to krigere der kamper til doden skiller dem ad. Jeg kan opleve dem som to kammerater der opøver deres ferdigheder som krigere.

Som billedmessig representation fremtrader de som silhuetter på en neutral baggrund hvor der ikke er noget der indikerer relationer til et miljø - jo der er stenene $i$ bunden af montren. De forbinder sig med silhuetterne og kommer til at reprasentere strand og dermed befinder krigerne sig på en mäske for den ene af dem fremmed strand hvor der kampes til sidste mand. Den ene af dem vil blive den sidste.

De er fremstillet i en meget grov teknik som en slags papirriv - og det giver en meget rå skildring af krigerne. Hver kriger har i den ene hånd en repræsentation af et sværd som er meget grov men som forfines gennem forbindelsen til de sværd der hænger ned fra loftet i montren. I den anden hånd har de noget som i sammenhængen må fortolkes som et skjold. Den ene af mændene har et langt strittende skæg og måske har de også en slags hjelm på - men det er ikke særlig tydeligt.

De to krigere står underligt $\mathrm{i}$ forhold til at de slås. Skjoldet burde jo være foran deres kroppe for at de kan beskytte sig men det understreger at det ikke er nogen naturalistisk skildring af en begivenhed. De er både $\mathrm{i}$ formudtryk og $\mathrm{i}$ indholdet meget stiliseret. De minder gennem valget af profil og gennem de strittende arme og skjold som mere ser ud som en tyk ring om helleristninger. Det er de ikke - de er helt klart en nutidig fortolkning af to krigeres relationer.

Silhuetterne er helt røde - og konnoterer kraft, energi, blod; det er voldsomme personer der kæmper til den ene mister blodet og farven. Men der er flere konnotationer på spil. De to silhuetter på stranden kommer til at konnotere overfald og krig. Og dermed knytter de sig til myten om vikingerne som overfaldsmænd og erobrere og krigere.

Roland Barthes (1964/1980:53) skriver om konnotationer at de udgør en arkitektonisk opbygning af tegn som er hentet fra en variabel mængde af leksisser, hvor hver enkelt leksis er kodet. Jo længere man stiger ned $i$ et individs psykiske dybder, jo sjældnere og mindre klassificérbare bliver tegnene.

Og hvis man kan se ovennæunte konnotationer som almene og kendte så kan vi stige længere ned i de måske mere private konnotationer.

Der er nogle primært kropslig funderede konnotationer nemlig at jeg som barn har leget med sværd og skjold og krydset klinger og banket løs på min legekammerats skjold. Men det var også organiseringen af grupper af 'krigere' der skjulte sig og angreb og dermed er det fremkaldelsen af 
58 en række kropslige erfaringer og viden om hvor helvedes ondt det gjorde når vi ramte ved siden af. $\mathrm{Og}$ som voksen forbinder der sig med mine egne drenge som skulle have nogle rigtig flotte skjolde - og hvor vi sammen producerede nogle meget smukke efterligninger af Prins Valiant og Sir Lancelots skjolde. Men her kom også farligheden ind $\mathrm{i}$ billedet når drengene brugte lange lanser og var tæt på at komme rigtig til skade.

Hermed har jeg også introduceret hele den mediemæssige påvirkning og de relationer som det er så nemt at skabe. For montren med vikingernes sværd og økser kalder også på tegneseriernes fremstillinger af vikinger og riddere og den nordiske mytologi og så alt det andet som jeg har læst gennem tidens løb og som er glemt som kilde men som er husket som en slags viden og oplevelse.

Montren fremkalder også Bayeux-tapetet. Dels som den fantastiske tegneserie det også er - men især oplevelsen af at være i Bayeux hvor vi gik op af de smukke og storslåede trapper til det smukke slot og så den lange vandring gennem fortolkninger af Bayeux-tapetet til vi endelig kom ind i det sorte hellige og hemmelig rum: det rigtige autentiske tapet. Og her kom overraskelsen: var det ikke større? Jo det var langt. Men det var jo ikke et tapet fra gulv ril loft - kun $70 \mathrm{~cm}$ højt. Igen denne overraskelse over at reproduktioner af udsnit og ordet tapet tilsammen skaber en forestilling om noget andet end det faktisk var.

\section{DEN BESØGENDE FORVANDLES TIL TING}

Jeg har gjort så meget ud af denne lille del af udstillingen om Oldtiden fordi det er her jeg møder et menneske. Men der er to elementer der mødes: en udstillingsdel og en beskuer. Som beskuer medbringer jeg en masse spredte stumper af viden og oplevelser. Medieret viden som er hentet fra bøger og tegneserier og billeder og film. Og en kropslig viden som er hentet fra legen med sværd og skjolde og fra legen med mine egne børn.

I denne del af udstillingen er der rudimenter af en fortælling, en fortolkning og en gestaltning. Her er der en repræsentation af mennesker der er involveret $i$ en handling og som har en relation til hinanden og som jeg som beskuer kan relatere mig til.

Der er rudimenter af en fortælling fordi jeg kan forbinde silhuetterne og stenene og forestille mig hvad der mon sker lige nu! - hvad der er sket lige for dette frosne billede er 'taget' og hvad der vil ske i den nærmeste fremtid. Det er hvad man kan kalde en indfoldet fortælling. Den har ikke en klassisk udfoldet fortælling begyndelse, midte og slutning - men som beskuer kan jeg tilføje og videretænke fortællingen. I fortællingen skabes en sammensmeltning af 'billedet', fortælleren og beskueren til en amalgam (Berger 1982: 285).

Jeg møder et menneske: jeg møder en (institutionel) fortæller som vil noget med mig og jeg møder et personligt udtryk (silhuetten af de to krigere i sin kontekst).

I Oldtiden kan man finde andre tegninger, fotografier og tekster - men det som karakteriserer dem er at de er meget 
neutrale og objektiviserende.

$\mathrm{Og}$ så er der ting. Oldtiden er udstillet i 23 større og mindre rum og der er et overvældende antal genstande. Der er 10.000 ting. Plus én meget vigtig ting - nemlig mig som besøgende.

Hvordan kan det være at alle disse kedelige, grove, forfinede, kendte, overraskende, sjove, dramatiske, smukke ting kan fortælle så lidt? Når jeg går rundt i Oldtiden så bliver jeg tiltalt på den samme måde. Jeg har mulighed for at få en stor viden om fundsteder og tiden og funktionen af den enkelte genstand. Jeg får en viden som relaterer sig til hvem, hvad, hvor, hvornår - men ikke ret meget hvorfor.

Hvis vi ser på Oldtiden gennem teorien om de fire oplevelsesfelter (Gjedde \& Ingemann 1999) - så får jeg megen konkret viden og jeg kan få aktiveret den skjulte viden jeg så kan forbinde med de ting jeg ser. Men der er meget lidt det i udstillingen gøres for at aktivere andre oplevelsesfelter: hvad er der som aktiverer mine kropslige handlinger? hvad er der som provokerer mine holdninger? hvad er der som tydeliggør mine værdier?

Der ligger nogle spor i udstillingen som kan provokere mine følelser: det er fx de meget smukke ting som Solvognen og Gundestrup-karret og flere andre ting og det som kunne tydeliggøres er at de alle er produceret i det fremmede. De er fundet i Danmark - men deres oprindelse kunne provokere mine følelser og blive en del af en diskussion om det multietniske samfund. Men det er en fortælling som udelukkende skal produceres af den besøgende.

Der er hvad der er og hvis udstillingen ikke ønsker andet end at formidle den fak- tuelle viden hvad sker der så ved det? Umberto Eco (1979:185) mener at teksten indeholder en forventning om en række kompetencer som læseren har og det er valg af sprog, valg af leksikalsk viden, kendskab til stil og genrer. Gennem disse valg indsnævres billedet af det som Eco kalder modellæseren som altså er indbygget $\mathrm{i}$ teksten og som endda produceres af teksten.

Hvordan tales der til mig som besøgende? En almindelig tekst er denne (som er placeret $\mathrm{i}$ bunden af montren med de to røde krigere):

Vikingerne rådede over en række veltrænede krigerenheder. De professionelle krigere, der var i tjeneste $i$ kongens og stormændenes personlige livvagter (hird), udgjorde hærens grundstamme. Når kongen kaldte til opbrud i krigssituationer, skulle landsbyer og gårde også stille med krigere til landets hær.

I 994 angreb Svend Tveskæg og Olav Tryggvason England med 94 skibe og ca 3.000 mand. Kun en del var sandsynligvis professionelle krigere, og mange var sikkert indkaldt til formålet. De omfattende angreb på England $\mathrm{i}$ den sene vikingetid viser, at vikingerne mestrede landbaseret krigsførelse med store hærstyrker. Dette krævede en høj grad af militær organisation med især et effektivt forsyningsafsnit. Svend Tveskægs hær på 3.000 mand krævede således daglige forsyninger af 4,5 tons fødevarer.

Teksten taler til mig ved at informere mig. Jeg får en viden om vikingernes militære organisation og omfanget af hæren ved angrebet på England $\mathrm{i}$ år 994. Men jeg skal være samler, samler af data.

Men - og det er min pointe - teksten taler til mig som objekt. Jeg er en slags beholder der samler viden sammen og som selv skal omforme det til en fortælling. Gennem den objektive og neutrale frem- 
60 stilling forvandler teksten mig til den objektive og neutrale datasamler.

\section{TEKSTEN DEFINERER LAESEREN}

Tekstens form og indhold definerer læseren og hvordan læseren kan aktivere sig selv i forhold til teksten. Men teksten i sin kontekst er som en flaskepost der er afsendt og som måske samles op af beskueren og bruges som han eller hun nu kan.

Men den objektiviserende tekst giver ikke mange cues.

Det er hvad den narrative tekst kan.

Den narrative tekst er karakteriseret ved at den har en fortælling - med en kanonisk narrativ struktur, hvor temaet præsenteres $\mathrm{i}$ begyndelsen, med en setting og hvor der er en vis kausalitet og temporalitet, med en løsning på det som er forbundet til kernehandlingen. Det indebærer også en personificering. Desuden gøres der på det semantiske plan brug af billeddannende og emotivt sprog (Gjedde 1999:22).

En flaskepost med en narrativ struktur og et billeddannende og emotivt sprog nærmer sig beskueren og beskuerens indre narrativer. De indre narrativer kan ses som de indlejrede strukturer hvorigennem vi som beskuere og læsere strukturerer vores oplevelser.

I den citerede tekst ovenfor er der ingen narrativ struktur. Der er intet billeddannende eller emotivt sprog - og der er ikke gjort noget forsøg på at skabe en tiltale til læseren. Der er centrale ord som '...rådede over...; '...angreb...'; '...mestrede...'; '...krævede...'; - altså en fremstilling af magt og initiativ knyttet til vikingerne. Der er intet i teksten der anskueliggør overfald, erobring, vold, død, ødelæggelse, årsager. I en traditionel journalistisk tekst har man ønsket om at teksten indeholder et svar på stedet for begivenheden (her England); indblandede $\mathrm{i}$ begivenheden (her er der kun vikinger); årsag (her angribes der men ikke hvorfor - er der sult og nød i Danmark?); konsekvenser (hvor mange englændere blev dræbt - og hvad skete der efter erobringen eller var det kun et røvertogt for at samle værdifulde ting?).

Teksten slutter med '...hær på 3000 mand krævede således forsyninger af 4,5 tons fødevarer' - og det er en rudimentær antydning som læseren kan gribe fat og forestille sig noget velkendt. Mad. Og i så stor en mængde.

Når Oldtidens tekster og kontekster fastholder beskueren på et objektiverende plan - så betyder det ikke blot noget for hvordan jeg som beskuer kan aflæse og forstå ting og kontekster - det går langt videre. Når jeg går gennem Oldtiden og kommer til den sidste af de 23 sale og den sidste af de 10.000? ting - så er jeg selv forvandlet til en ting. Nr 10.001?

Det sker på tre måder:

Det sker for det første ved at gå igennem den enorme ophobning af ting.

Det sker for det andet ved at jeg gennem hele udstillingen bliver tiltalt som et objekt - dvs. uden følelse og værdier.

Det sker for det tredje ved fraværet af menneskelige relationer. $\mathrm{Og}$ det er det mest afgørende. Jeg kan se spor af menneskelige aktivitet: spor af håndværkeren $\mathrm{i}$ stenøkserne og smykkerne og sværdene og... og jeg kan overraskes over de trepanerede kranier; men der er meget få spor af mennesker der handler $\mathrm{i}$ forhold til hinanden og af hvilke relationer de kan have haft til hinanden. 


\section{TING - SET AF ET BLIK}

In the simulacrum of objects all images and resources can be considered of equal status... we do not follow the division of sources of information between the primary (the object itself), secondary (facts about the object) and tertiary (interpretation of the object) that is normally upheld within the culture of museums. (Beardon\&Worden 1995:75).

Beardon\&Worden anskuer museet indefra med en nedvurdering af tingenes værdi i sig selv og de faktuelle informationer og en opvurdering af fortolkningen. Men set fra den beskuers synsvinkel der selv er blevet forvandlet til en ting så er det langt alvorligere.

Når ting møder ting - kan der ske ingenting. Når ting møder mennesker - kan der ske alting. Jeg møder den meget simple repræsentation af to mænd der slàs med sværd - og jeg kan skabe en rudimentær fortælling ud fra billedet i sin kontekst. Det er en slags fortolkning.

Jeg har brugt montren med billedet af de to krigere og sværdene og økserne og stenene som et 'fællesbillede' på hele udstillingen om Oldtiden (Lindberg 1991:279). Montren er en slags metonym for hele udstillingen og den bliver brugt symbolsk til at fortælle myten om vikingerne som krigere, overfaldsmænd og røvere. Men det er et 'fællesbillede' af en særlig slags - det er her set som et udtryk for det som ellers er temmelig fraværende på udstillingen.

Jeg har argumenteret for at netop fraværet af mennesker og deres relationer både $\mathrm{i}$ Oldtiden og $\mathrm{i}$ relationen mellem udstillingen og den besøgende - er med til at fastholde den besøgende $\mathrm{i}$ rollen som ting. Det kræver en meget vidende og levende og aktive besøgende at forblive som menneske og tilføre tingene det liv og de menneskelige relationer som der ikke er mange cues til i udstillingen. Sheldon Annis (1987:171) mener at

The magic that makes museums so attractive may lie in the flexibility with which people create their own space. Museums are more than the sum of their labels and their designed order. Like the objects in them, museums do not have a meaning. Rather, they accept and reflect the meanings that are brought to them.

Annis gør det for enkelt. Jeg kan være enig $i$ at det er den besøgende der bringer betydning til museet og at museet må acceptere og reflektere den besøgendes betydning. Men det er for enkelt. Som institution og som producent af betydning kan man have større mål. Hvis man bare vil acceptere og reflektere alle betydninger der bringes ind $\mathrm{i}$ udstillingen - så findes der ingen mål for den 'gode' udstilling. Hvis man bringer to ting sammen - så vil vi som beskuere prøve at finde en betydning og en relation mellem de to ting. Det er vores iboende trang til at skabe betydning. Det er en meget firkantet udgave af en postmoderne tænkning hvor betydningsdannelsen ligger hos beskueren. Men udgangspunktet for betydningsdannelsen er stadigvæk en 'tekst' altså ting, tekster, billeder, design, rum. Og denne 'tekst' er produceret af nogen med et formål. Museet er ikke blot en udstilling af ting. Museet er formidling og kommunikation i et samfund (Ingemann 2000a).

Som beskuer ønsker jeg at nogen vil tage mig ved hånden og fortælle. Det narrative ligger også i tingene. Tingenes mulige historier kan pakkes ud. 
62 Annis mener ikke det er nødvendigt. Han laver en analogi mellem det ekspressionistiske maleri - og museets udstilling af ting. Han tager Chagalls billede 'The Man and the Sentry'. Her kan vi se ting som er disassocieret fra den virkelige verdens relationer. De frigjorte ting bliver symboler eller i det mindste igangsættere. En mands ansigt balancerer på en hest (en rygende hest, et rygende hus) fra hvilken en skildvagt marcherer. En hest, hus og skildvagt $i$ stedet for en torso; de hviler på kødfulde (mandlige) ben som sidder på en stol.

Annis mener 'There is a contextual disorder, but it is precisely the disorder that makes the work provocative' (1987:169). Han finder beskueren har en dobbelt glæde: først ved at afprøve kunstnerens emotionelle resonans og afprøve ens egen reaktion til forslaget (er der en hest og en skildvagt inden i mig); og for det andet en intellektuel proces med at sammenfatte og gætte igen og fortolke kunstneren og hans symboler (var der en hest og en skildvagt inden i Chagall?).

Det ekspressionistiske maleris symboler er flade og fastfrosne. Beskueren kan kun stå foran fladen og projicere sig selv ind $\mathrm{i}$ billedet. Annis ser museet som et symbolsk landskab som mere er tredimensionalt end todimensionalt. Den besøgende kan bevæge sig ind $i$, igennem og forbi.

Når Annis laver analogien mellem det ekspressionistiske maleri og museets udstilling af ting - så mener han altså at tingene også er arbitrært placeret og kan opleves på samme intense måde som når vi ser på Chagalls maleri. Passer det?

Det kan passe hvis det er en kunstner af Chagalls format som har placeret og kombineret de ting som er samlet på udstillingens 'lærred'. Alle mulige ting kan kombineres på et lærred og siges at udgøre en slags symbolsk udtryk men det som gør at et værk kan siges at være et stærk og provokerende udtryk - og et andet værk bare er kedeligt og uinteressant afgøres vel af den samlende helhed og den intention som skaberen har haft.

Det provokerende og fortællende ligger ikke $\mathrm{i}$ tingene $\mathrm{i}$ sig selv - men netop $\mathrm{i}$ at ting sættes sammen for at skabe en indre eller ydre version af hvordan et menneske ser verden og denne verdens ting. Alle ting kan ikke skabe relationer som ligheder eller forskelligheder eller modsætninger.

Montren med de to røde krigere - og sværdene og økserne og stenene - har ikke denne provokative virkning. De er det bedste bud på hvordan mennesket kan komme til syne $\mathrm{i}$ udstillingen om Oldtiden. Men det kræver en meget modtagende og medskabende beskuer for at det er muligt at aflokke dette helhedsbillede betydning.

Paper fremlagt på Museologisk Netværks seminar den 23.-24. marts 2000.

\section{LITTERATUR}

Annis, S. (1987): 'The museum as a staging ground for symbolic action' in Museum 151 p. 168-171. Barthes, Roland (1964/1980): 'Billedets retorik' in Fausing, B. \& Larsen, P.: Visuel Kommunikation (1), København: Medusa.

Beardon, C. \&Worden, S. (1995): 'The virtual curator: multimedia technologies and the roles of museums' in Barretr, E. \& Redmond, M. (ed): Contextual multimedia and interpretation, London: The MIT Press. 
Berger. J. (1982): Another way of telling, London: Writers \& Readers.?

Eco, U. (1979): 'Læserens rolle' in Olsen, M. (ed): Vark og laser, København: Borgen.

Gjedde, L. \& Ingemann, B. (1999): 'In the beginning was the experience', paper fremlagt på 14 . Nordiske konference for medie- og kommunikationsforskning 14.-17 august 1999 (under publicering).

Gjedde, L. (1999): 'Fortællingens dimensioner', del af ph.d. afhandling Kommunikation/Roskilde Universitetscenter.

Ingemann, B. (2000a): 'Ti teser om museets rolle i samfundet' in Nordisk Museologi nr. 1/2000 p. $\mathbf{x x}-\mathbf{x x}$.

Lindberg, A.L. (1991): Konstpedagogikens dilema. Historika rötter och moderna strategier, Lund: Studentlitteratur.

\section{SUMMARY}

\section{A Man in Ancient Times}

Is it possible to find people in the Antiquity Section at the National Museum of Denmark? There are of course the visitors. But what about traces of the people of ancient times and the relations they may have had with each other?

In twenty-three rooms filled with 10000 objects there is only one representation of people - a picture in an exhibition case of two red Vikings fighting.

Here I meet a man. The only one embedded in the objects.

The main point is that as a visitor I am transformed into an object. Number 10001 . I am myself nearly placed into an exhibition case.

My objectification takes place in three ways:

firstly by walking through the enormous accumulation of objects;

secondly the fact that as a visitor I am addressed as an object - i.e. without feelings and values;

thirdly by the absence of human relations. And that is the most important way. I can see traces of human activities: traces of the crafts person in the stone axes, the pieces of jewelry and the swords; I may be surprised by the trephined skulls but there are very few traces either of the humans who had relations with each other or of the kinds of relations they may have had.

We can see experience as consisting of four fields: the knowledge field, the action field, the emotional field and the value field (Gjedde\&Ingemann 1999). Almost the only field that is activated in the exhibition is the knowledge field. And even this happens in a very objective and distant way. If we accept the theory of inner narratives e.g. that all we hear or read or see is understood through a narrative structure, then in the context of the objects the written text and the visual representation in the concrete showcase and in fact the whole exhibition provides practically nothing that can function as cues for the visitor on which to construct his or her inner narrative.

The American museologist Sheldon Annis (1987: 171) believes that "The magic that makes museums so attractive may lie in the flexibility with which people create their own space. Museums are more than the sum of their labels and their designed order. Like the objects in them, museums do not bave a meaning. Rather, they accept and reflect the meanings that are brought to them."

This statement can be seen as a version of a postmodern thinking where the creation of meaning is located in the visitor. On one level I agree with that point of view but it does free the museum from having a goal. The museum is not only an exhibition of objects. The museum is arrangement and communication within a sociery (Ingemann 2000a).

The exhibition case with the Vikings and the swords and axes creates and supports the myth of the Vikings as warriors, robbers and rapists or at least there is nothing that calls the myth into question. As a visitor you may bring this preconceived knowledge with you and the exhibition will activate 
64 an understanding that will confirm your preconception.

The experience fields of emotion and value and action are almost untouched by the exhibition except in so far as a visitor has a stereotypical experience.

Exhibited objects need interpretation to unlock their stories. It is necessary to construct narratives and a clear artitude to the stories to be told is required.

The unlocking and telling are not in the objects themselves but in the placing of the objects together to create versions - spiritual and material - of how man sees the world and the objects in the world.

The idea of leaving the creation of meaning totally to the visitor is to recreate the himself as an object.

Bruno Ingemann, ph.d., lektor ved Kommunikation,

Roskilde Universitetscenter.

Adr. Kommunikation, Roskilde Universitetscenter,

Po.Box 260, DK-4000 Roskilde

Fax +4546743075

e-mail:bruno@ruc.dk 